Jnl. Soc. Pol. (2021), 50, 2, 406-437 C The Author(s), 2020. Published by Cambridge University Press. This is an Open Access article, distributed under the terms of the Creative Commons Attribution licence (http:// creativecommons.org/licenses/by/4.0/), which permits unrestricted re-use, distribution, and reproduction in any medium, provided the original work is properly cited. doi:10.1017/S0047279420000288

\title{
A lost decade? A renewed case for adult social care reform in England
}

\author{
JON GLASBY* (D), YANAN ZHANG** (D), MATTHEW R. BENNETT** (D) AND \\ PATRICK HALL*** (D)
}

${ }^{*}$ School of Social Policy, University of Birmingham

** Department of Social Policy, Sociology and Criminology, University of Birmingham

${ }^{* * *}$ Health Services Management Centre, University of Birmingham

\begin{abstract}
Drawing on a 2010 analysis of the reform and costs of adult social care commissioned by Downing Street and the UK Department of Health, this paper sets out projected future costs under different reform scenarios, reviews what happened in practice from 2010-19, explores the impact of the growing gap between need and funding, and explores the relationship between future spending and economic growth. In the process, it identifies a lost decade' in which policy makers failed to act on the warnings which they received in 2010, draws attention to the disproportionate impact of cuts on older people (compared to services for people of working age) and calls for urgent action before the current system becomes unsustainable.
\end{abstract}

Keywords: adult social care; long-term care; older people; disabled people; learning disability; mental health; carers

\section{Background and introduction}

For many years, there has been widespread awareness (among policy makers, practitioners, researchers, people using services, their families and the media) that the adult social care system in England needs fundamental reform. While health care is delivered via a National Health Service available to all based on clinical need and largely free at the point of delivery, adult social care (practical assistance for frail or disabled people with activities of daily living such as getting up, getting washed/dressed, going to the toilet, eating etc) is organised locally by locally-elected Councils, is means-tested and access depends on meeting increasingly strict eligibility criteria. After an assessment of need by a social worker, care (if deemed eligible) may be provided from a mix of public, private and voluntary sector agencies, in a sector characterised by low status and low pay. Always organised differently and funded less generously than more universal services such as health care, adult social care has also faced a combination of pressures arising from demographic change and increased costs, rising need and demand, and the pursuit (since 2010) by successive governments of a policy of 
austerity and cuts to public expenditure. This article reviews the reform and costs of adult social care, drawing on initial analyses commissioned in the late 200os to inform government policy in the run up to the 2010 General Election (Glasby et al., 2010). These informed, and were quoted, in a subsequent White Paper (HM Government, 2010, p.52) which set out ambitious plans for the creation of a 'National Care Service', with much greater similarities to the National Health Service than to the previous highly targeted, discretionary and poorly funded adult social care system. With the election of a new government in 2010, this was never implemented; the subsequent austerity agenda led to nearly a decade of spending cuts, service pressures and a growing sense of crisis. By 2019, there were almost daily warnings of the potential collapse of the current system, severe and adverse impacts on people with care and support needs (and their families), a mounting workforce crisis, the bankruptcy of a series of large care providers, and well-publicised abuse scandals (National Audit Office, 2018; BBC, 2019a-b; Holt, 2019; Local Government Association, 2019; House of Lords Economic Affairs Committee, 2019).

Against this background, this paper reviews what happened to adult social care spending from 2010 to the present day, comparing this with the reform and spending scenarios we set out in 2010. Given a massive shortfall in available funds and the financial/service pressures facing adult social care, we also explore how the growing gap between need and funding is currently being plugged - and the severe impacts this is having on people's lives. The paper then projects future funding and its share of regional gross value added (GVA, a common measure of the value of goods and services), enabling us to set out spending on adult social care as a proportion of the overall value of the economy to 2060. To our knowledge, this is the first analysis of its kind to present policy makers with different scenarios for adult social care funding and reform, to view these in practice (by comparing them to nearly a decade of policy) and to set out the relationship between future economic growth and the provision of sustainable adult social care. In the process, the paper sets out the very different ways in which spending has changed for working age adults and older people, with older people bearing the brunt of social care funding cuts in terms of unmet need, greater levels of self-funding, poor quality and greater pressure on families. This paper focuses on the adult social care system in England, but most developed countries are struggling with similar pressures (Colombo et al., 2011). This was also the case even before the world-wide recession (Tarricone and Tsouros, 2008; Australian Government Productivity Commission, 2010; Glendinning, 2010), and current pressures are not merely the product of austerity. 


\section{Adult social care reform and funding up to $\mathbf{2 0 1 0}$}

In 2010, Downing Street and the (then) Department of Health commissioned a review of the social and economic benefits of adult social care reform (Glasby et al., 2010). We described an English social care system widely recognised as 'broken', by commentators, policy makers, service users and families alike. Our report outlined the drivers of increasing social care demand, including demographic change and changes in family structure. We discussed the sources of perceived injustices in the existing system, including rising public expectations and increasing concerns about geographical and economic equity. We described a sense of 'crisis' in terms of funding, fairness and perception and provided an overview of the recent history of adult social care policy responses to these issues, setting out five key rationales for reforming adult social care:

1. Maintaining social and public expectations that the state will provide a degree of collective support to its most vulnerable citizens;

2. Supporting people to have greater choice and control over their services, and hence over their lives;

3. Enabling people to remain independent for as long as possible so that their needs do not deteriorate into a future/costly crisis;

4. Providing support to those in need so that they can contribute fully as active citizens; and

5. Reducing some of the negative impacts of poor social care on families and individuals who care for others.

In addition, we reviewed the evidence for five potential mechanisms for reform pursued by successive governments over time which seemed likely to continue to influence future policy:

1. Strategic commissioning - seeking best value for money by securing services from a mixed economy of care;

2. Greater collaboration between health and social care (on the assumption that local agencies working together might meet needs more effectively and reduce the costs of operating independently of each other);

3. Personalisation - utilising direct payments and personal budgets to achieve better outcomes for either the same (or potentially slightly less) money for some user groups;

4. Technology - with potential to provide better support to people through a system of telecare as well as to improve the efficiency of current working practices;

5. Workforce reform - reducing the costs associated with unfilled vacancies, use of agency staff and absenteeism. 
In particular, we reviewed the impact each of these reform mechanisms might potentially have, setting out three future scenarios for future adult social care reforms and costs. In 2002, a formal review of health care spending commissioned by the government and undertaken by Sir Derek Wanless, a leading banker, projected different spending scenarios for the NHS. This was picked up with enthusiasm by the (then) New Labour government and led to significant increases in NHS funding in order to try to achieve a 'fully engaged' scenario (Wanless, 2002, preface: Letter to the Chancellor of the Exchequer) in which:

"Levels of public engagement in relation to their health are high. Life expectancy increases go beyond current forecasts, health status improves dramatically and people are confident in the health system and demand high quality care. The health service is responsive with high rates of technology uptake, particularly in relation to disease prevention. Use of resources is more efficient."

Although the Review also recommended a similar process be undertaken in social care, this recommendation was not taken up by the government. Building on this approach, we set out three similar scenarios for social care:

- Slow uptake: future policy and practice remain as now, with periodic attempts to more fully integrate health and social care, but without sustained and real change; little permanent workforce reform; some support for carers; ongoing preventative/rehabilitative pilots, but a failure to embed these in mainstream services; and low uptake of technology. This scenario describes a system which tries to meet basic social expectations by providing a bare minimum, albeit with some aspiration to higher quality and more responsive rightsbased services. Despite a stated commitment to longer-term change, action is limited and sporadic, with the commitment more rhetoric than reality. Under this scenario, costs increase at a rate of $2 \%$ per year (Figures $3 \mathrm{a}-\mathrm{c}$ ), leading to a doubling of adult social care costs within two decades.

- Solid progress: while the stated aims of policy remain similar, there is a more concerted effort to improve outcomes and deliver savings through integration; a greater understanding/embedding of the principles of personalisation; a genuine and sustained attempt to rebalance mainstream services towards a more preventative/rehabilitative approach (i.e. to move away from a 'firefighting' approach which focuses on meeting the needs of people in crisis, to one which can increase investment in prevention and rehabilitation to help people remain living independently at home, or to return home after a spell in hospital if they have experienced some sort of crisis in their health); a sustained commitment to a commissioning-led system ${ }^{1}$; greater support for carers; significant workforce reform; and more innovative use of IT. In practice, the intended benefits are not fully realized to quite the extent envisaged (for example, integration does not deliver as much as expected, and the impact 
of personalisation is reduced by professional and cultural barriers). Over time, thinking retreats to meeting basic needs, extending some rights and trying to boost prevention/rehabilitation. Under this scenario, costs are contained at current levels.

- Fully engaged: there is a sustained commitment to genuine change, motivated by a desire to realize in full the benefits for the health and social care system and for wider society. Where the evidence base is currently contested or unclear, the mechanisms used surpass expectations and start to really deliver. Thus, partnerships achieve the outcomes/savings that intuition suggests they ought; commissioning proves an effective lever for reforming the system; personalisation is experienced as a lived reality by front-line staff and service users; there are high rates of technology take-up; and there is effective and ongoing workforce reform. This approach is underpinned by a genuine commitment to a rights-based approach, to mainstreaming prevention and rehabilitation, and to using social care funding to achieve a much broader range of social and economic benefits for users and carers. Under this scenario, there is a $2 \%$ reduction in costs (albeit the assumptions about what may be possible to achieve verge on the heroic).

To our knowledge, this was the first time the 'Wanless scenarios' - influential in persuading New Labour to significantly increase NHS spending, essentially tripling the health care budget over their period in office - were applied to adult social care, and the first analysis to present policy makers with such detailed projections for different levels of commitment to reform. Ultimately, our review highlighted the high costs of inaction - on existing demographic trends and with standard cost assumptions, we concluded that the real costs of adult social care (that is, after allowing for inflation) could double within two decades. Moreover, this would be the case for current services and approaches (which had already been strongly criticised for failing to fully and appropriately meet need), leading to significantly higher costs with no improvement in the quality of care. Even under our most optimistic and demanding scenario of 'full engagement', real spending on social care would merely be held at its 2010 level.

\section{Adult social care policy and funding since $\mathbf{2 0 1 0}$}

Following the defeat of New Labour in 2010, the newly elected Conservative/ Liberal Democrat Coalition rejected the previous administration's White Paper, publishing its own 'Vision for Social Care' (HM Government, 2010). This set out seven key principles for reforming the adult social care system, focusing on prevention, personalisation, partnership, plurality, protection, productivity and people (Department of Health, 2010, p.8). Despite their 
impressive alliteration, these felt no different to previous policy commitments. The new government also committed to producing a new White Paper, and creating a sustainable legal and financial framework for adult social care by building on two key reviews: a legal review (commissioned by the New Labour government in 2008) led by the Law Commission, and a review of funding options for long-term care (chaired by Sir Andrew Dilnot).

The Law Commission's review (Law Commission, 2011), published in May 2011, surveyed over sixty years of social care law since the National Assistance Act 1948. It concluded that the law had become confusing and unclear, and proposed a single statute that would integrate existing duties while updating them with best practice in terms of personalisation, safeguarding and commissioning (key parts of the current system, but lacking a statutory basis). Its core recommendation was to establish a new, positive legal basis for social care: the duty of local authorities to promote individual wellbeing, as opposed to 'meeting need'. This would also necessitate local authorities thinking about the wellbeing of the population, not just those individuals fitting pre-defined eligibility criteria.

In July 2011, 'Fairer Care Funding': the report of the Commission on Funding of Care and Support was published (Dilnot, 2011). This argued that care remains the last large uninsurable social risk: private insurers had failed to produce products that enable people to pool this risk through the market, and individuals can face catastrophic costs that cannot be predicted in advance (no one knows who will need care and who will not). In response, the report proposed raising the asset threshold from the existing $£_{23}, 250$ to $£_{100,000}$, expanding the number of people who would receive state-funded care. It also proposed a cap on the amount any individual would contribute to their care (potentially $\mathfrak{E}_{35}, 000$ ), thereby helping individuals to plan ahead for future care costs and encouraging the insurance industry to develop new products.

The government then published a Draft Care and Support Bill (HM Government, 2012) in two parts, corresponding to each Commission's recommendations, later enacted as the Care Act (HM Government, 2014). This represented the largest overhaul of adult social care law since the establishment of the welfare state. Part One of the Care Act was implemented in April 2015, alongside other support documents and statutory guidance. The Act:

- Defined adult social care as the promotion of individual wellbeing

- Placed a duty on local authorities to promote prevention and integration

- Established a new right to assessment for carers

- Placed a duty on authorities to maintain an information and advice service for all residents

- Placed a duty on authorities to facilitate a diverse, vibrant and sustainable market for care and support services that benefit the whole population 
- Established a right to advocacy if a person lacks the capacity to be fully engaged in statutory social care functions

- Established national eligibility criteria for social care assessments

- Placed a duty on authorities to make safeguarding enquiries and establish an 'Adult Safeguarding Board' made up of local stakeholders, including the NHS and police.

Part Two of the Care Act set out the government's response to the Dilnot Commission. It set an increased upper capital limit of $£_{118,000}$ for care home residents (including the value of their home) and $£ 27,000$ for those who receive care at home. It also set an increased lower capital limit of $£ 17,000$ and an overall

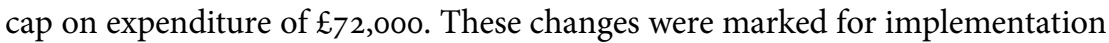
in April 2016. Government also set out an aspiration that by defining care cost liability, interest in developing care insurance products would be stimulated in the private insurance market.

Although Part Two of the Care Act was much less generous than recommended by the Dilnot Commission, the newly elected Conservative government (2015-) baulked at its practical and cost implications and delayed enactment of Part Two of the Act, later abandoning it altogether (see Jarrett, 2018, 2019 for an overview of a number of the key events set out in the paragraph below). Following Theresa May's election as leader, the Conservatives pledged to publish a Green Paper putting forward new proposals. During the 2017 General Election campaign (Conservative Party, 2017), the government set out ideas even further removed from the Dilnot recommendations: eschewing the lifetime cap and proposing to include the value of people's homes when means-testing for home care (as well as for residential care). Negative reaction to the proposals was seen as a key factor in the loss of the Conservative's overall majority, with many perceiving the changes to be regressive and/or a reduction in service. Political opponents labelled the changes a 'Dementia Tax', and the policy (which seemed to have been developed in a small inner circle without adequate consultation and debate) quickly unravelled. During a press conference to discuss the proposals, May declared 'nothing has changed' while also announcing a possible cap on costs and that yet further proposals would be set out in the government Green Paper, previously announced in the March 2017 Budget. In the context of Brexit negotiations, the government has delayed this Green Paper's publication multiple times; it remains unpublished at time of writing. There have been at least 12 government Green/White Papers, vision documents and independent reviews since 1999 (Jarrett, 2019), yet we are no closer to reforming the funding of adult social care than twenty years ago. Indeed, of proposals relating specifically to funding, none of the main recommendations have been implemented, and it is difficult to believe it will be $13^{\text {th }}$ time lucky. 


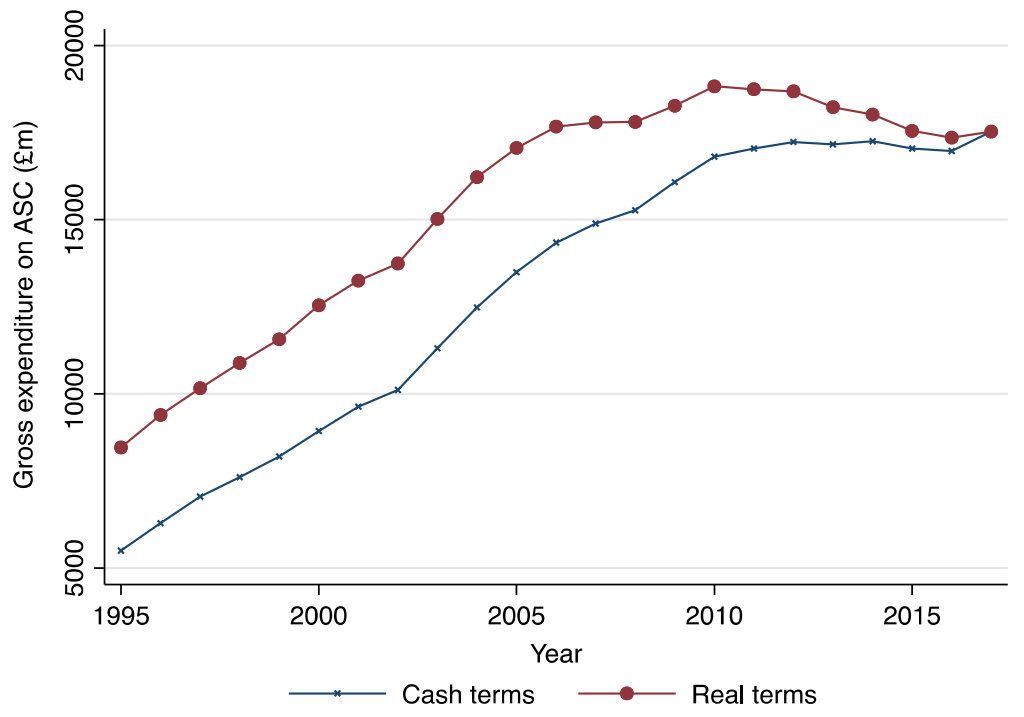

Figure 1. Gross expenditure on adult social care

Source: Adult Social Care Activity and Finance Report, England 2017-18 for 2009-2018, NHS Digital; Personal Social Services: Expenditure and Unit Costs England, 2007-08 for 1994-2008, NHS Digital; GDP deflators at market prices, and money GDP September 2018, HM Treasury, 2018

In spite of the focus of the Care Act on promoting wellbeing, many have argued that the laudable intentions of the new legislation were instantly undermined by the 'austerity' agenda begun by the Coalition Government in 2010. This was described by one council leader as 'the end of local government as we know it' (Glasby, 2015) and the Local Government Association calculates councils will have lost almost 6op in every $\mathfrak{E}_{1}$ central government provides for local services (2010-20) (https://www.local.gov.uk/about/news/fundingblack-hole). Our own analysis (Figure 1) shows that local authority spending on adult social care increased in real terms until 2011. Thereafter it declined (despite increases in need and demand), with an $8 \%$ reduction in gross spending between 2009-10 and 2015-16. Moreover, Figure 2 shows a massive reduction in the real growth rate of gross spending on adult social care and in the ratio of gross spending to Gross Value Added. Although councils protected social care expenditure relative to other areas of local government expenditure over the period, additional demographic pressures, broader funding pressures and increases in costs (such as the implementation of the National Living Wage) have culminated in a sense of 'crisis' in publicly funded adult social care services, and per adult spending fell by $13.5 \%$ over the period (Humphries et al., 2016). In recognition of these pressures, piecemeal injections of additional funding have been needed (for example, with government allowing local authorities to place 


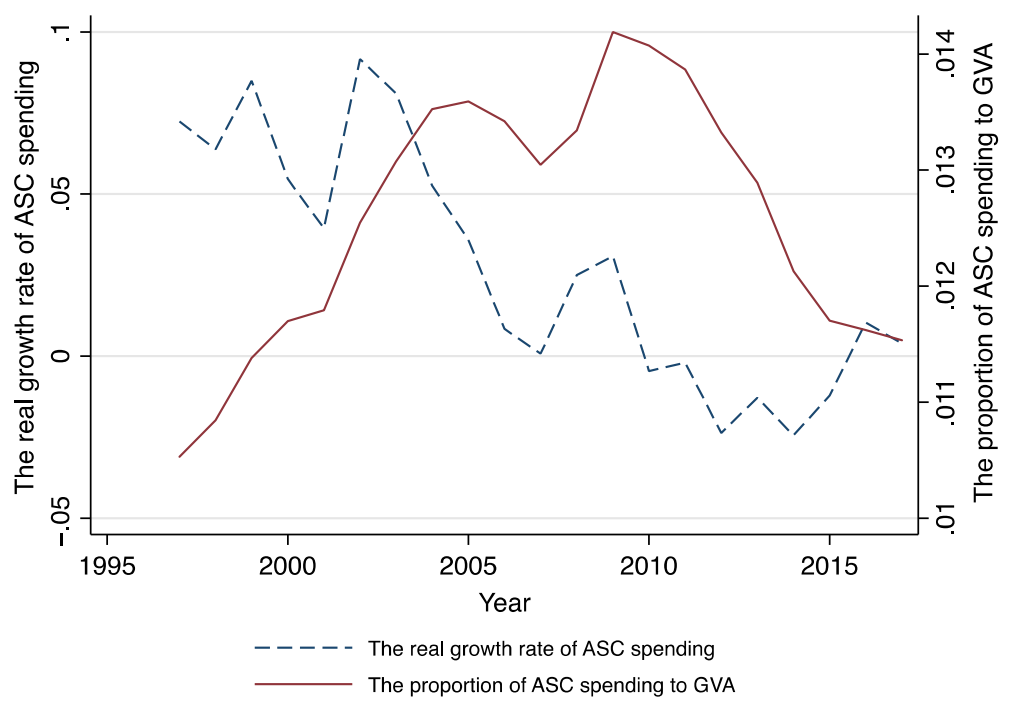

Figure 2. Real growth rate of gross expenditure on adult social care

Source: Adult Social Care Activity and Finance Report, England 2017-18 for 2009-2018, NHS Digital; Personal Social Services: Expenditure and Unit Costs England, 2007-08 for 1994-2008, NHS Digital; GDP deflators at market prices, and money GDP September 2018, HM Treasury; Regional gross value added (income approach), December 2018, ONS.

an additional charge on local Council Tax, and some transfers of funding from NHS budgets). Consequentially, gross adult social care spending reached $£ 17.53$ billion, with a slight in-year increase in 2017 (albeit still lower than in 2010) (Cromarty, 2019).

Returning to our 2010 analysis, we characterise the last ten years as a lost decade' for adult social care. Although the Care Act is now on the statute book, its influence on what is happening has in practice been minimal. Indeed an early review carried out by the Minister responsible for steering the legislation through Parliament found that (regarding the experience of carers, at least) the new law was too often poorly understood or ignored - and that the answer to the question of 'has this made a difference?' was 'not yet' (Carers Trust, 2016). Moreover, for many commentators, the failure of successive governments to move beyond platitudes and re-statements of previous policy towards anything substantive has been simply appalling (see, for example, Glasby, 2015; Humphries et al., 2016; Butler, 2018; House of Commons Health and Social Care and Housing, Communities and Local Government Committees, 2018; Age UK, 2019; Johnson, 2019). There is no evidence of any real progress with the five main reform mechanisms we identified in 2010 and, indeed, quite a lot of evidence that previous attempts to pursue such policies have either stalled or gone backwards (Table 1). 
TABLE 1. Progress with key reforms

\begin{tabular}{|c|c|c|}
\hline Reform mechanism & Evidence of potential impact (Glasby et al., 2010) & Progress since 2010 \\
\hline $\begin{array}{l}\text { Strategic } \\
\quad \text { commissioning }\end{array}$ & $\begin{array}{l}\text { A key feature of government policy over time, albeit limited } \\
\text { international evidence for the claims made by policy makers } \\
\text { (particularly in health and care services) }\end{array}$ & $\begin{array}{l}\text { Significant reaction against market-based reforms in English health } \\
\text { and social care (e.g. Dickinson et al., 2013; Hudson, 2016). High } \\
\text { profile provider failures have raised further questions about the } \\
\text { ability of 'commissioning' to deliver aspirations }\end{array}$ \\
\hline $\begin{array}{l}\text { Health and social care } \\
\text { partnerships }\end{array}$ & $\begin{array}{l}\text { Longstanding belief that joint working may improve outcomes and } \\
\text { reduce costs - albeit evidence of the latter is limited. Projections } \\
\text { from one very integrated health and social care system suggested } \\
\text { scope for significant impact on use of NHS resources }\end{array}$ & $\begin{array}{l}\text { Health and social care partnerships remain challenging, with a } \\
\text { tendency for national policy/local initiatives to over-promise and } \\
\text { under-deliver. The integrated system used as a basis for our } \\
\text { initial } 2010 \text { projections (Glasby et al., 2010) was abolished as a } \\
\text { result of the Coalition's health reforms (Farnsworth, 2012). } \\
\text { Subsequent policy has been perceived as focusing more on } \\
\text { internal NHS integration than on health and social care }\end{array}$ \\
\hline Personalisation & $\begin{array}{l}\text { Promising early results from pilots and an early national evaluation } \\
\text { - albeit this is a complex and contested area of policy and } \\
\text { practice, and the nature of the evidence base is widely debated }\end{array}$ & $\begin{array}{l}\text { Some positives for individuals achieved, but significant } \\
\text { disillusionment with how this policy has been implemented in } \\
\text { practice, in a difficult financial environment. One of the } \\
\text { architects of these reforms has described the risk of 'zombie } \\
\text { personalisation' rather than genuine transformation (Duffy, } \\
\text { 2014) }\end{array}$ \\
\hline Technology & $\begin{array}{l}\text { In other non-care sectors, technology is transforming the delivery } \\
\text { of services and traditional ways of working - albeit benefits in } \\
\text { adult social care have been more limited }\end{array}$ & $\begin{array}{l}\text { Aspirations remain high, but evidence of actual change and of } \\
\text { significant financial savings remains limited. A high profile } \\
\text { government policy to promote telecare produced } \\
\text { underwhelming results when formally evaluated (Henderson } \\
\text { et al., 2014) }\end{array}$ \\
\hline Workforce reform & $\begin{array}{l}\text { Significant scope to reduce costs via tackling vacancies, turnover, } \\
\text { sickness and use of agency staff }\end{array}$ & $\begin{array}{l}\text { Failure to tackle longstanding issues, rising sense of a workforce } \\
\text { crisis and highly critical report by the National Audit Office } \\
(2018)\end{array}$ \\
\hline
\end{tabular}


Of the three scenarios set out in 2010, this is worse than 'slow uptake', and had funding remained available - we would expect the cost of adult social care to have rocketed. However, adult social care spending is heavily constrained by the availability of local government funding more generally, and it is possible to shed light on these seeming impossible financial and service pressures by comparing what happened in practice with our initial 2010 projections (Figure 3a-3c).

Between 2008 and 2014, local authority spending on social care for working-age people with physical impairments, learning disabilities or mental health problems was broadly consistent with or slightly above a 'slow uptake' scenario (increasing at an overall rate of around $2 \%$ per year). Given broader cuts to local government funding, this is a significant cost pressure - but spending has at least (broadly) kept pace with what we might have expected from our 2010 projections. Over the same period, however, spending on older people's social care departed dramatically from our projections. In Figures $3 b-3 c$, spending on older people (both on their residential/nursing care and on community services including home care services) fell significantly in real terms, to well below the levels needed to sustain previous services, even in the most challenging, ambitious and optimistic of our scenarios.

Given the 'lost decade' summarised above, a significant gap has thus opened between the rising cost of maintaining current services and the actual money spent. Actual spending on residential/nursing care for older people in 2018 was $\mathfrak{E}_{4,449}$ million, for instance, while projected spending, under a 'slow uptake' scenario, was $\mathfrak{E}_{7,066}$ million. Actual spending in 2013 and projected spending under a 'slow uptake' scenario on day and domiciliary provision for older people were $\mathfrak{k}_{2,872}$ million and $\mathfrak{E}_{3,739}$ million respectively. This raises profound questions about the impact this disparity may be having on service users, staff and other services.

\section{The impact of spending reductions}

With need and costs projected to rise significantly, and spending, especially on older people's services, falling dramatically, our review of the evidence/analysis suggests that six key impacts are emerging:

1. Increasing levels of unmet/under-met need and rising levels of 'self-funding': based on an analysis of the English Longitudinal Study of Ageing, Age UK (2018) estimates that the number of older people who do not receive adequate support with 'Activities of Daily Living' (getting out of bed, going to the toilet, getting washed and dressed, etc.) increased to 1.4 million people in 2017. This means one in seven older people (14\% of the $65+$ population) was living with some level of unmet need (an increase of 19\% since 2015). 
(a)

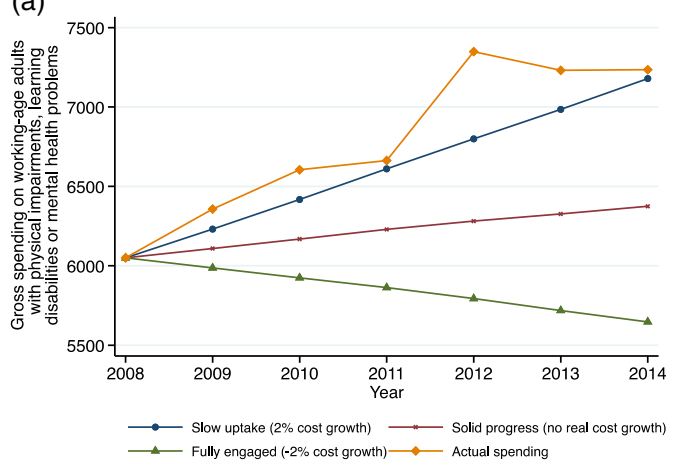

(b)

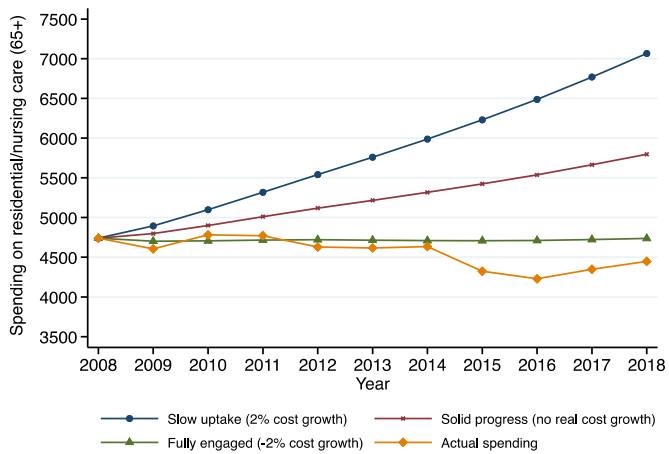

(c)

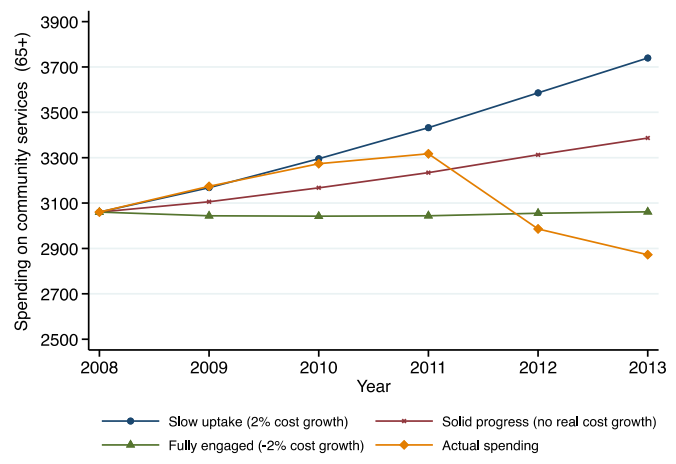

Figures 3. a-c: Projected v actual spending (public adult social care funding) at 2008 prices, 2008-

a. Gross spending on working-age adults ( $\mathfrak{E m}$ in real terms) with physical impairments, learning disabilities or mental health problems

b. Spending on residential/nursing care for older people (65+) ( $\mathrm{Em}$ in real terms)

c. Spending on community services for older people - day and domiciliary provision ( $£ \mathrm{~m}$ in real terms)

Source for all 3 Figures: Glasby et al. 2010; Personal Social Services: Expenditure and Unit Costs England, 2007-2015, NHS Digital; Adult Social Care Activity and Finance: England, 2016-18, NHS Digital 
When the definition is broadened to 'Instrumental Activities of Daily Living' (shopping, cooking, managing medication, etc.), the number of older people who do not get the help they need rises to 1.6 million. Overall, an estimated 400,000 fewer older people are receiving social care as eligibility criteria have tightened in response to insufficient resources (Age UK, 2018). When this happens, extra pressure is placed on families (see below) and more people are forced to make their own arrangements, as best they can, in the absence of public support, by arranging and paying for their own care where this is feasible. Although it is difficult to obtain accurate information on levels of self-funding, latest UK Household Longitudinal Survey (UKHLS) data suggest around 350,000 people fund their own home care or care home places in England, many more than previously thought (Henwood et al., 2018). Moreover, unlike other areas of life where having financial resources opens up new choices and opportunities, self-funders tend to be isolated, marginalised and disadvantaged compared to people receiving publicly-funded support, and pay a premium of some $40 \%$ for their residential/nursing care, effectively cross-subsidising council-funded residents (Henwood et al., 2018).

2. Quality of care: where people are receiving social care support, there are increasing pressures on quality. The House of Commons Health and Social Care and Housing, Communities and Local Government Committees observe (2018, p.12):

"The quality of care provided is also suffering. We heard it described as 'extremely patchy', 'variable' and that the care given to people with dementia was often lower quality... Caroline Abrahams, Charity Director at Age UK, explained how the challenges in the workforce affected quality: lack of continuity, never seeing the same person twice [...] rushed visits - maybe quarter of an hour rushing in and out - with no time to establish a proper relationship, let alone real communication'."

3. Pressures on carers: the growth in unmet need is also reflected in growing pressure on carers (family members, friends and neighbours who provide unpaid support for people with social care needs). In the annual budget survey of Directors of Adult Social Services, well over a quarter felt cuts to services had already reduced quality of life for carers, and many more expected this to be the case in future (ADASS, 2019). In the State of Caring survey 2019, over one-third of carers (37\%) responding described themselves as "struggling to make ends meet", while only one in ten felt confident that the support they receive and rely upon will continue (Carers UK, 2019). Nearly three-quarters $(72 \%)$ said they had suffered mental ill health as a result of caring and $61 \%$ reported physical ill health as a result of caring. Data provided by NHS Digital (2019a) suggest that the proportion of carers reporting negative effects on their health has increased since 2016-17, with 
more carers reporting feeling tired, having disturbed sleep, general feelings of stress and feeling depressed.

4. Pressures on staff: a review of the adult social care workforce (National Audit Office, 2018) identified high overall turnover rates (27.8\% in 2016-17) and vacancy levels (6.6\% in 2016-17, and even higher for the care worker and registered nurse sub-categories), exacerbated by the difficulty of recruiting to low paid, low status roles. The House of Commons Communities and Local Government Committee (2017) has also drawn attention to the stressful and uncertain nature of care work, with many members of social care staff facing low wages, zero hours contracts and poor training. In $2018,47.8 \%$ of care workers left within a year of starting (p.3) and the mean number of sickness days for directly employed adult social care staff in local authorities was 10.3 days per year (compared with 4.3 days for all workers nationally) (NHS Digital, 2019b, p.19).

5. Pressures on service providers: as the gap between need and funding widens, the provider market - mainly for-profit providers - has faced severe and sustained financial pressures. In 2017, a Competition and Markets Authority study of care homes in England (Competition and Markets Authority, 2017) concluded that existing (primarily publicly-funded) care home markets would prove to be unsustainable at current rates paid by local authorities. The ADASS (2019, p.30) Budget Survey revealed that "75\% of Councils (up from 66\% last year) reported that providers in their area had closed, ceased trading or handed back contracts in the last six months, with thousands of individuals affected as a consequence." There have also been widespread media reports of national providers (both in home care and residential care), such as Allied Healthcare and Four Seasons, facing severe financial problems and potential bankruptcy (Care Quality Commission, 2018).

6. Pressures on partner agencies: when access to adult social care is significantly reduced, pressure can increase on the NHS (a universal service, free at the point of delivery, and unable to 'say no' to people in need in the way adult social care can). In recent years, vociferous campaigning to boost adult social care spending by various NHS bodies (see, for example, Dickson, 2019) has seen the NHS use its greater popularity, visibility and political capital to advocate on behalf of social care partners. A particular pressure point has been older people medically fit for discharge from hospital who are unable to vacate their bed due to lack of capacity in community services. Internal NHS factors account for most delays, but since 2010 waiting for social care services has grown as a reason for this. By October 2018, the most common reason for delay was patients awaiting a care package in their own home (rolling average of 1,008 patients delayed per day) while the third most common was awaiting a nursing home placement (rolling average of 673 patients delayed per day). Between August 2010 and February 2017, 1,185 more 
patients per day were delayed for social care-related reasons, a $96 \%$ increase (Nuffield Trust, 2019). Most debate has centred on the knock-on effects of the social care crisis on the NHS, but pressures have also been reported on the police and other services (see, for example, Cottam, 2018). Our 2010 analysis also demonstrated that spending on adult social care can affect people's ability to work and social security spending, so it seems likely cuts in adult social care and social security also affect other partner agencies.

\section{Long-term cost projections}

Our cost projections for adult social care are based on assumptions about the proportion of people who will receive support from local authorities, the movement of the population, changes in the unit cost of social care and Gross Value Added (GVA), and stability in adult social care policies (see Annex for details). Existing studies focus on projecting adult social care spending (e.g. Wittenberg et al., 2018), but do not explore if local authorities and the government can meet increased care demand. Tax revenue, a primary resource for adult social care support, is closely related to local economies, which can be measured by GVA. We therefore use GVA as a proxy for government's financial capacity and project the ratio of gross spending on adult social care to GVA. The purpose of this projection is to emphasise the importance of the government budget (economic growth) when examining the sustainability of the adult social care system.

Our data source for adult social care expenditure is the finance return (PSSEX1), now replaced (from 2014) by the Adult Social Care Finance Return (ASCFR). The ASC-FR introduces new classifications [Long-Term (LT) and ShortTerm (ST) support], posing comparability problems post-2014, especially for primary support and service provision. LT support refers to continuous care to maintain an individual's quality of life, provided in a nursing, residential or community setting; ST support is time-limited and aims to maximise an individual's independence, reducing their future need for support. Based on the new classification framework, we project gross spending on LT and ST support for older people $(65+)$ and the working-age population, as well as the corresponding ratio of spending to total GVA, for 2018 to 2060; our projections are based on the three scenarios used in our 2010 analysis. We assume that the proportion of older people who receive support from local authorities for LT or ST support are constant. With constant ratios and 2016-based population projections from the ONS, we project the number of people receiving support. Projected costs are the product of the number of people receiving support, the real costs of this in 2018 and the assumed growth rate of real costs. From 1997 to 2018, the average GVA growth rate in real terms was approximately $2 \%$. We therefore assume 
TABLE 2. Projected gross spending on long-term care for older people $(65+)$ $(\mathfrak{E m})$

\begin{tabular}{lcccccc}
\hline & 2018 & 2020 & 2030 & 2040 & 2050 & 2060 \\
\hline $\begin{array}{l}\text { The number of people } \\
\quad \text { receiving care }\end{array}$ & 565,385 & 583,681 & 715,094 & 826,567 & 886,864 & 945,613 \\
$\begin{array}{l}\text { Spending - fully engaged } \\
\text { Spending - solid progress }\end{array}$ & 7100 & 7039 & 7047 & 6655 & 5834 & 5083 \\
Spending - slow uptake & 7100 & 7330 & 8980 & 10380 & 11137 & 11874 \\
\hline
\end{tabular}

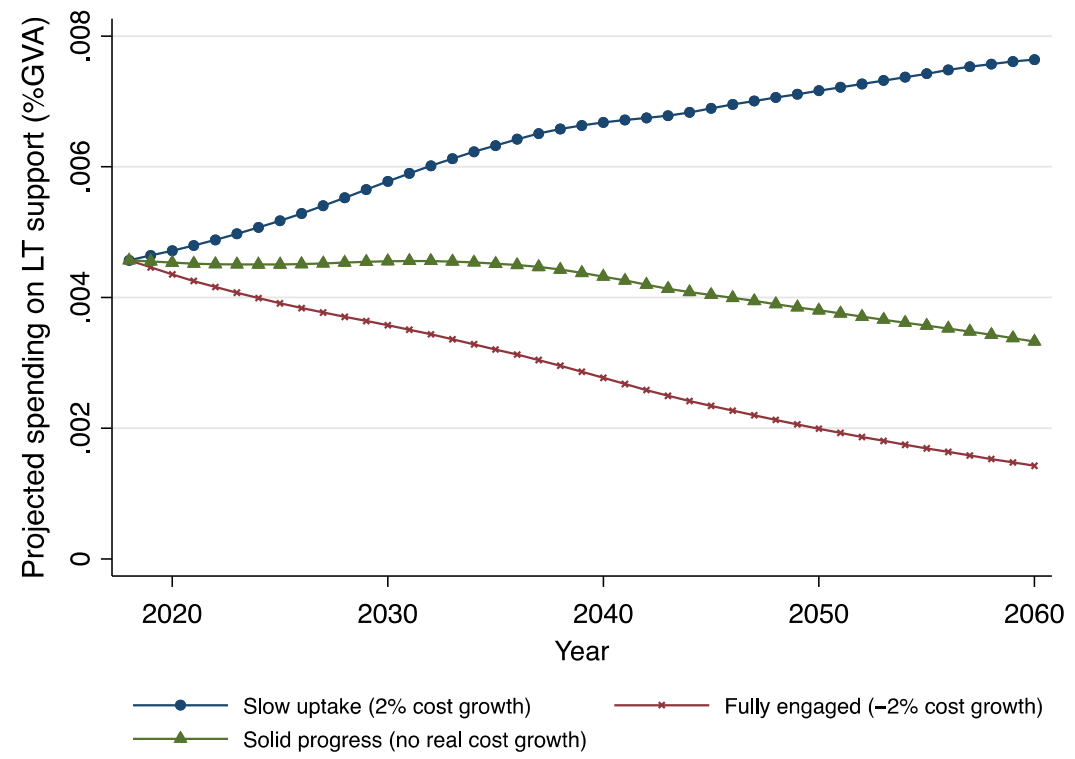

Figure 4. Projected gross spending on long-term support for older people (\% GVA) Source: 2016-based population projection, ONS; Regional gross value added (income approach), ONS; Adult Social Care Activity and Finance: England, 2017-18, NHS Digital

GVA increases by $2 \%$ annually for our projection period. The ratio of spending on adult social care to GVA is calculated by dividing projected spending by GVA.

We assume that the number of people who receive local authority funded care support changes with ONS population projections. In 2018, 565,385 people aged $65+$ received LT support; this increases to 945,613 in 2060 (Table 2). For 'slow uptake' and 'solid progress' scenarios, projected gross spending on LT support for older people increases, respectively, from $£_{7,100 \mathrm{~m}}$ in 2018 to $£ 27,279 \mathrm{~m}$

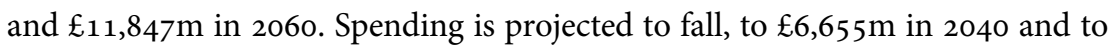
$£_{5}, 083 \mathrm{~m}$ in 2060 , under a 'fully engaged' scenario. Figure 4 displays the share of 
TABLE 3. Projected gross spending on long-term support for working-age people $(£ \mathrm{~m})$

\begin{tabular}{lcccccc}
\hline & 2018 & 2020 & 2030 & 2040 & 2050 & 2060 \\
\hline The number of people receiving care & 292380 & 293623 & 296468 & 299092 & 302984 & 304519 \\
Spending - fully engaged & 6871 & 6627 & 5467 & 4506 & 3730 & 3063 \\
Spending - solid progress & 6871 & 6900 & 6967 & 7028 & 7120 & 7156 \\
Spending - slow uptake & 6871 & 7179 & 8835 & 10866 & 13417 & 16439 \\
\hline
\end{tabular}

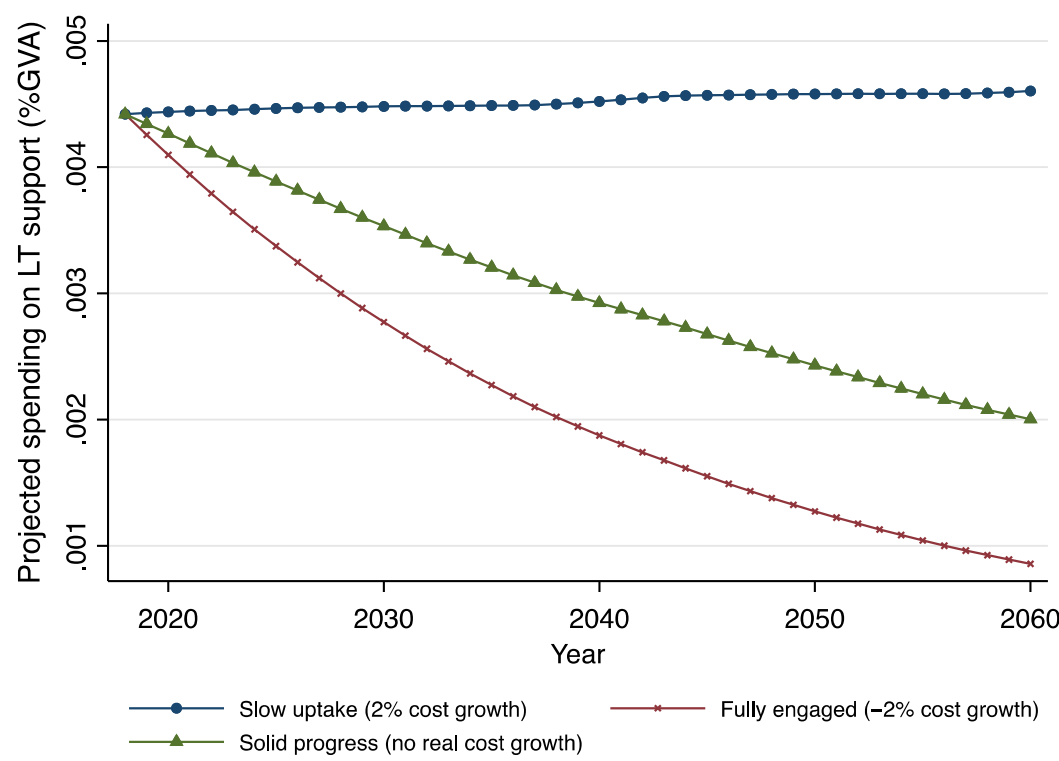

Figure 5. Projected gross spending on long-term support for working-age people (\% GVA) Source: 2016-based population projection, ONS; Regional gross value added (income approach), ONS; Adult Social Care Activity and Finance: England, 2017-18, NHS Digital

spending to GVA in England, which decreases in the 'solid progress' and 'fully engaged' scenarios, from $0.457 \%$ in 2018 to $0.333 \%$ and $0.142 \%$, respectively, in 2060. Under 'slow uptake', the share is projected to increase to $0.668 \%$ in 2040 and to $0.764 \%$ in 2060 .

In 2018, the number of working-age people receiving LT support was 292,380 (Table 3 ), increasing to 299,092 in 2040 and 304,519 in 2060 . In a 'fully engaged' scenario, spending on LT support will decrease from $£ 6,871 \mathrm{~m}$ (2018) to $£_{4,506 \mathrm{~m}}$ in 2040 and to $\mathfrak{Z}_{3}, 063 \mathrm{~m}$ in 2060 . Under 'solid progress' and 'slow

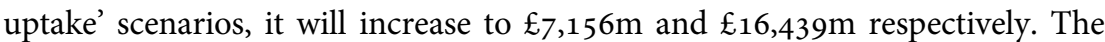
share of spending to GVA decreases from $0.442 \%$ in 2018 to $0.2 \%$ in 2060 with 'solid progress', and to $0.086 \%$ under a 'fully engaged' scenario (Figure 5). If the 
TABLE 4. Projected gross spending on short-term care for older people ( $\mathfrak{m}$ )

\begin{tabular}{lcccccc}
\hline & 2018 & 2020 & 2030 & 2040 & 2050 & 2060 \\
\hline Number of people receiving support & 183735 & 189681 & 232387 & 268612 & 288207 & 307299 \\
Spending - fully engaged & 400 & 396 & 397 & 375 & 329 & 286 \\
Spending - solid progress & 400 & 413 & 506 & 585 & 627 & 669 \\
Spending - slow uptake & 400 & 429 & 641 & 904 & 1182 & 1536 \\
\hline
\end{tabular}

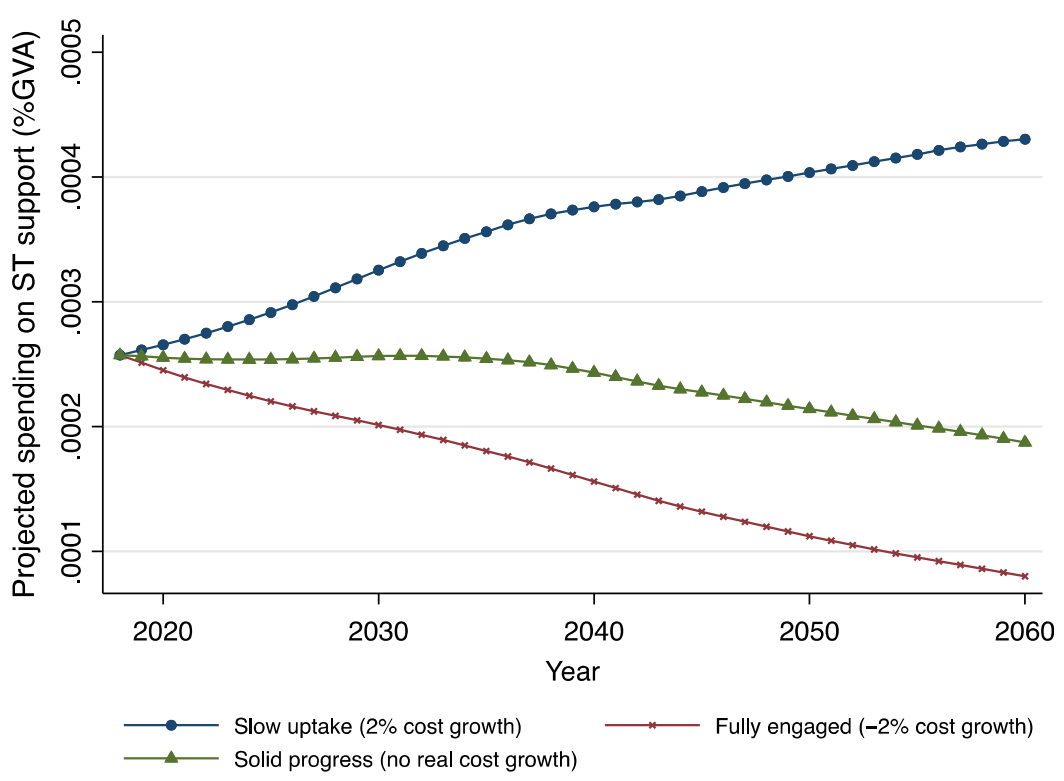

Figure 6. Projected gross spending on short-term support for older people (\% GVA) Source: 2016-based population projection, ONS; Regional gross value added (income approach), ONS; Adult Social Care Activity and Finance: England, 2017-18, NHS Digital

average cost increases by $2 \%$ annually ('slow uptake'), this share will increase to $0.452 \%$ in 2040 and to $0.46 \%$ in 2060 .

The number of people aged $65+$ receiving ST care was 183,735 in 2018 (Table 4) and projected to increase to 268,612 in 2040 and to 307,299 in 2060. Under a 'solid progress' scenario, gross expenditure will rise from $\mathfrak{E}_{400 \mathrm{~m}}$ in 2018 to $£ 669 \mathrm{~m}$ in 2060 , and to $\mathfrak{1}_{1,536 \mathrm{~m}}$ under a 'slow-uptake' scenario. Spending is projected to fall, to $£ 286 \mathrm{~m}$ in 2060 under a 'fully engaged' scenario, while the share of spending to GVA decreases to $0.008 \%$ (Figure 6). The share will also drop under a 'solid progress' scenario (to $0.019 \%$ ), although gross spending increases. We project that the share will increase to $0.043 \%$ under the 'slow uptake' scenario. 
TABLE 5. Projected gross spending on short-term care for working-age people $(\mathfrak{E m})$

\begin{tabular}{lcccccc}
\hline & 2018 & 2020 & 2030 & 2040 & 2050 & 2060 \\
\hline Number of people receiving support & 26665 & 26778 & 27038 & 27277 & 27632 & 27772 \\
Spending - fully engaged & 159 & 153 & 126 & 104 & 86 & 71 \\
Spending - solid progress & 159 & 159 & 161 & 162 & 164 & 165 \\
Spending - slow uptake & 159 & 166 & 204 & 251 & 310 & 379 \\
\hline
\end{tabular}

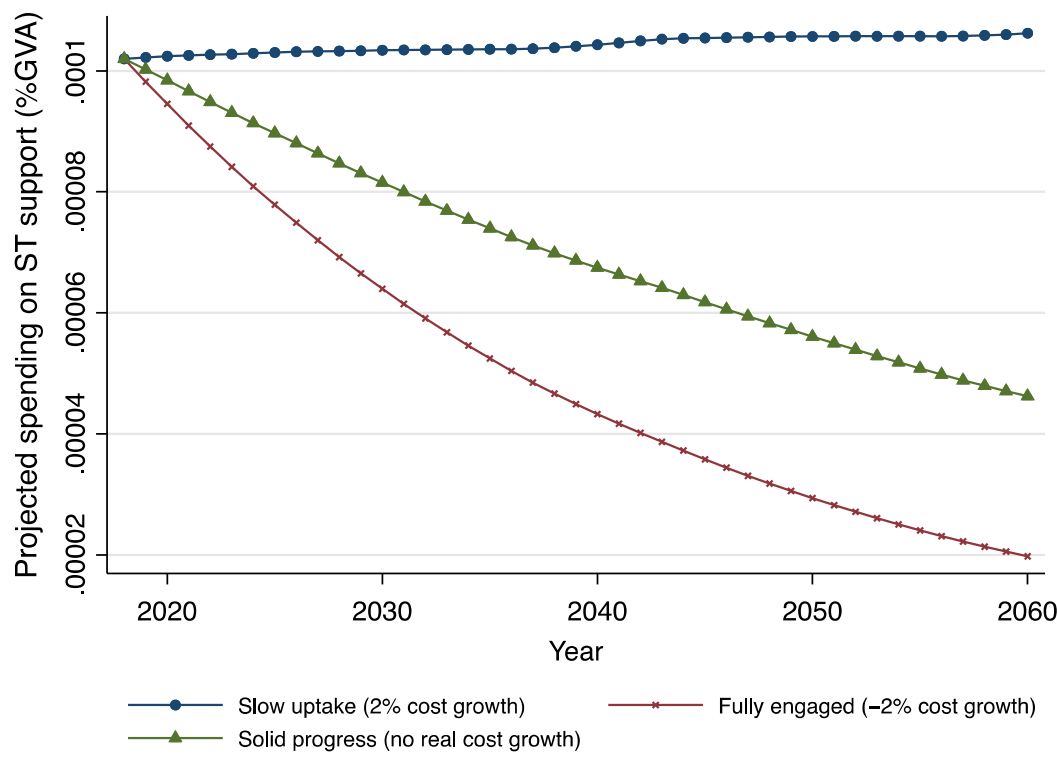

Figure 7. Projected gross spending on short-term support for working-age people (\% GVA) Source: 2016-based population projection, ONS; Regional gross value added (income approach), ONS; Adult Social Care Activity and Finance: England, 2017-18, NHS Digital

The number of working-age people receiving ST support was 26,665 in 2018 and will increase slightly, to 27,277 , by 2040 and to 27,772 by 2060 (Table 5). Gross spending on ST support for this group was $\mathfrak{E}_{159 \mathrm{~m}}$ in 2018. Spending is projected to remain constant and to increase slightly to $£ 165 \mathrm{~m}$ in 2060 under a 'solid progress' scenario. Under a 'fully engaged' scenario, however, spending will fall to $\mathfrak{E}_{71 \mathrm{~m}}$ in 2060 , while under a 'slow uptake' scenario it increases to $£_{379 m}$. Along with economic growth, the share of spending to GVA decreases dramatically under 'solid progress' and 'fully engaged' scenarios (Figure 7). The share will slightly increase (from $0.01 \%$ in 2018 to $0.011 \%$ in 2060) under a 'slow uptake' scenario. 


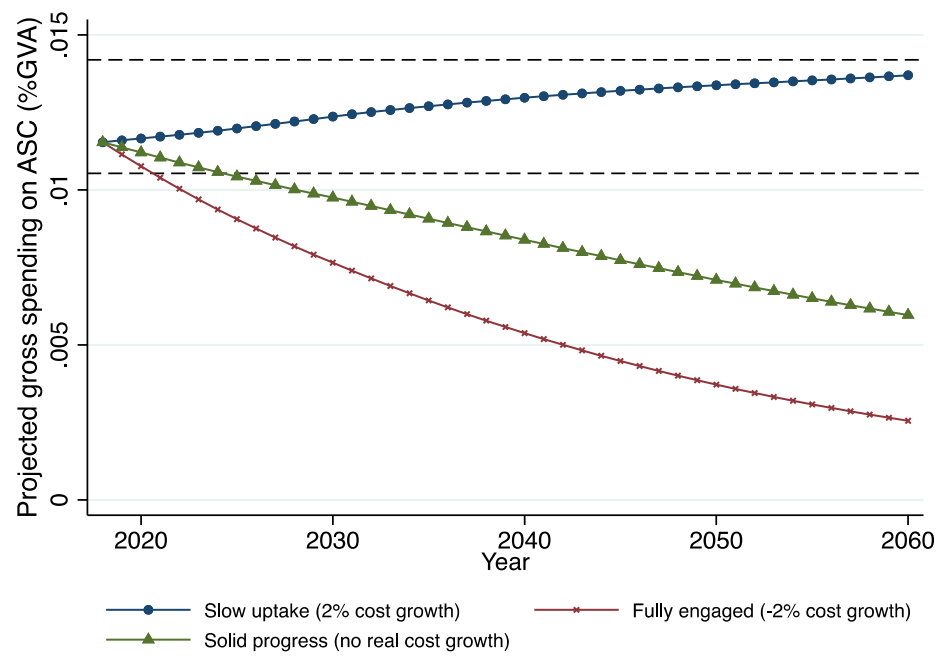

Figure 8. Projected gross spending on adult social care (\% GVA) Source: 2016-based population projection, ONS; Regional gross value added (income approach), ONS; Adult Social Care Activity and Finance: England, 2017-18, NHS Digital

Figure 8 displays the projected share of gross public spending on all adult care services to GVA. Between 1997 and 2018, the share reached a $1.419 \%$ high in 2009 and a $1.053 \%$ low in 1997; we include these historical upper and lower bound values (using dashed reference lines in the figure) to reference our projections. The proportion of gross spending on adult social care to GVA was $1.153 \%$ in 2018 - above the lower reference. Under a 'fully engaged' scenario, the share will decrease, and go below the lower reference, by 2021, as it will (by 2025) under a 'solid progress' scenario. Even in the 'slow uptake' scenario (where gross expenditure on adult social care is expected to increase), the share of spending to GVA will still be below the upper reference level. This suggests governments will be able to meet increased demand for adult social care if the economy grows at $2 \%$ annually, but that the availability of future funding for it is inextricably linked to the future performance of the economy.

Figures 9-11 show the projected share of gross spending under different growth rate conditions. In Figures 9-11, the growth rate of GVA is assumed to increase by $1 \%, 0.5 \%$, and $0 \%$, respectively. If governments maintain the current 'slow uptake' scenario, the share of gross expenditure on adult social care to GVA will exceed the upper reference line by 2031 (given $1 \%$ economic growth), 2028 (given $0.5 \%$ economic growth) and by 2026 (if the economy stays at 2018 growth levels). If the share exceeds the upper boundary, it may be difficult for government to meet increased demand for social care. When investigating 


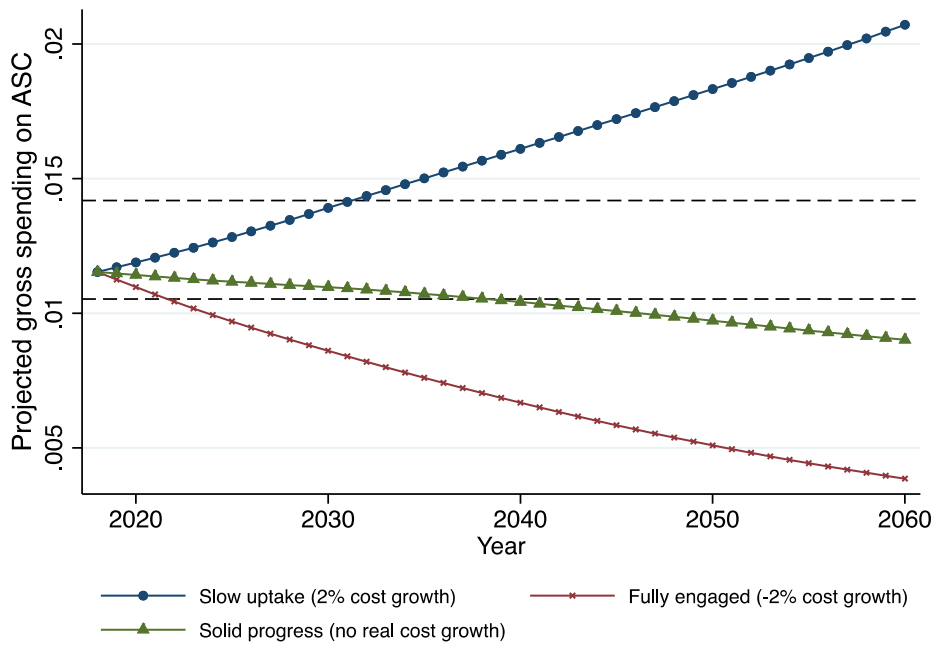

Figures 9 Projected gross spending on adult social care (\% GVA) - GVA increases by $1 \%$ annually

Source: 2016-based population projection, ONS; Regional gross value added (income approach), ONS; Adult Social Care Activity and Finance: England, 2017-18, NHS Digital

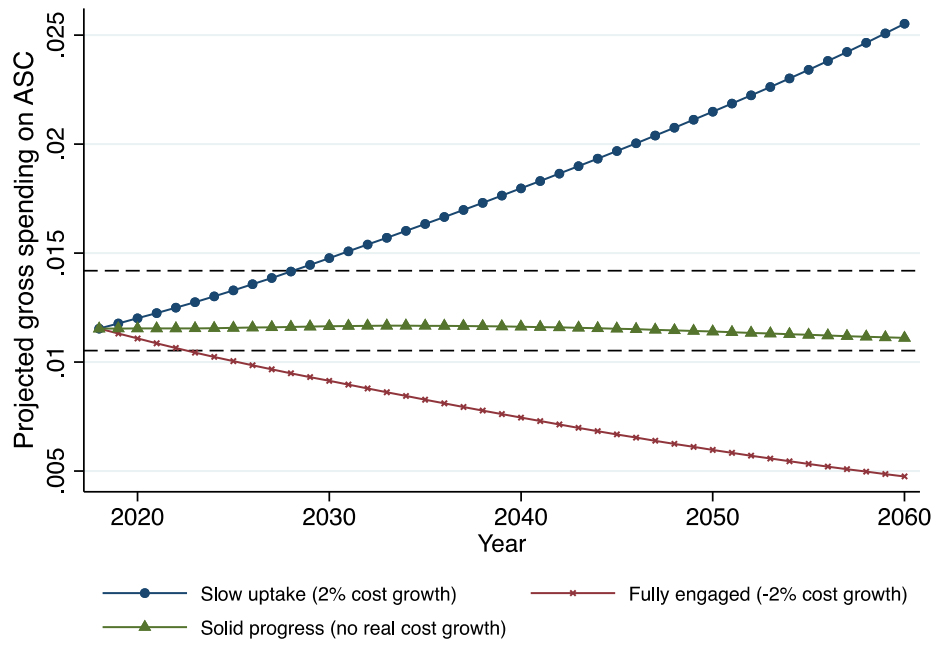

Figures 10 Projected gross spending on adult social care (\% GVA) - GVA increases by $0.5 \%$ annually

Source: 2016-based population projection, ONS; Regional gross value added (income approach), ONS; Adult Social Care Activity and Finance: England, 2017-18, NHS Digital 


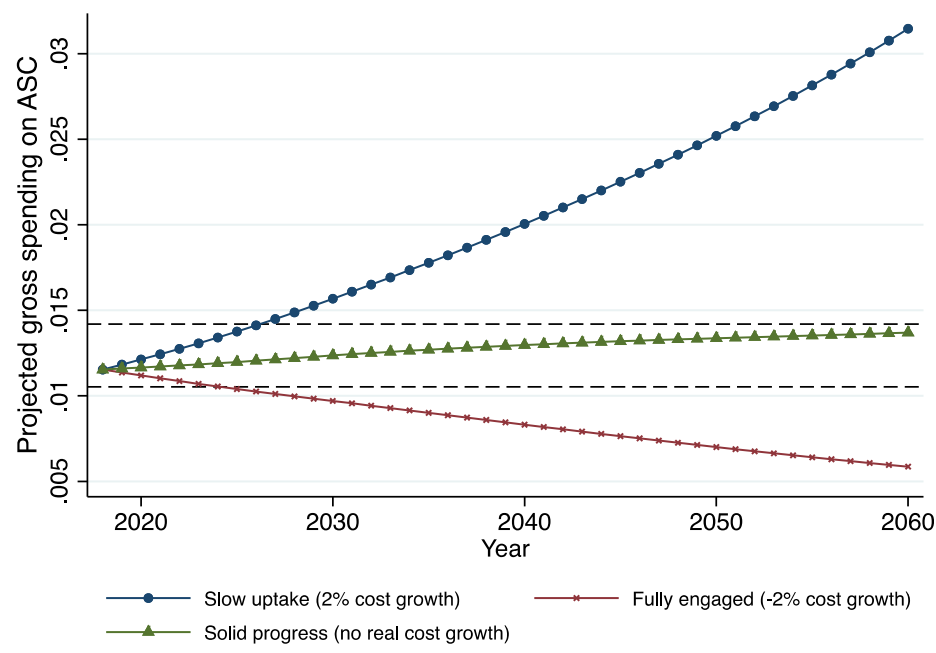

Figures 11 Projected gross spending on adult social care (\% GVA) - No increase in GVA Source: 2016-based population projection, ONS; Regional gross value added (income approach), ONS; Adult Social Care Activity and Finance: England, 2017-18, NHS Digital

sustainable funding for adult social care, our projections emphasise the need to consider economic growth and early implementation of reforms. As the population ages, the government's financial burden will increase, and available funds for implementing reform will decrease.

\section{Discussion and Conclusion}

This paper portrays 'a lost decade' in which previous reforms and New Labour's investment stalled and, in many cases, began to go backwards. Although our 2010 analysis concluded that 'doing nothing' was not an option, when New Labour lost the 2010 General Election, its proposed adult social care reforms were instantly jettisoned. Despite the Care Act 2014, policy in the subsequent decade has been even less ambitious than the 'slow uptake' scenario we presented to government as the least attractive/feasible approach (leading to no increase in quality and a doubling of adult social care costs within two decades). Predictably, the result has been greater unmet/under-met need, more self-funding, lower quality care, a crisis among care providers, and much greater pressure on staff, families and partner agencies. Unless something significant changes, current pressures will only increase, and the adult social care system will quickly become unsustainable (if this point has not already been reached).

The impact of these funding pressures is not being felt equally by older people and people of working age and their families. Although most of the media and policy debate on adult social care focuses on older people (the largest group of 
people using services), the discourse in broader society about the needs of older people has been extremely negative. In an era of austerity, there have been legitimate debates about the importance of intergenerational equity and the welfare of a younger generation facing significant economic challenges, increased levels of anxiety, rising higher education costs, less secure employment, rising house prices, less secure pensions and (latterly) reduced life expectancy (Kontopantelis, 2018; Shaw, 2018; Yates, 2019). Within adult social care, however, the cost of care for people of working age has risen largely as projected, while services for older people have been cut back severely. There have been vociferous campaigns about the poor quality of care provided to young people and adults with mental health problems and learning disabilities (Duffy, 2013; Mencap, 2016; TUC, 2018), yet the plight of older people has been much less discussed - despite being a national scandal which ought to generate just as much shock and anger. Underlying this situation, we identify three inter-related factors:

1. A significant number of young people with profound physical impairments, learning disabilities and/or mental health problems are entering adult social care services with very profound and expensive needs; their impairments mean they will need significant support for life. At present, there is little scope for reducing their need for services via greater prevention or more active rehabilitation, and costs are likely to increase as more people with such needs become adults and enjoy far greater life expectancy than in the past. This is a major achievement of the welfare state, and to be celebrated.

2. Expenditure cuts seem to be more acceptable when applied to older people than when they affect people of working age. Despite the legitimate needs of other groups, it is hard to interpret the trends in Figures $3 \mathrm{a}-3 \mathrm{c}$ and $4 \mathrm{a}-4 \mathrm{c}$ other than as (at least in part) the product of ageist attitudes and assumptions about the role and needs of older people. It seems services for older people can be cut in ways unimaginable - and which would certainly be more vehemently challenged - if they occurred in other service settings.

3. Many of the impacts summarised above involve people and their families suffering quietly in their own homes - the sheer human misery caused by our 'lost decade' is simply not as visible as financial pressures on more prominent, popular and better understood services (hospitals or schools, for example). When social care for older people is cut to the bone, lives are blighted, distress and pressure increase, and the resilience of individuals and their families is ground down. Yet this happens slowly - day by day, week by week and month by month. It is not sudden, dramatic or hi-tech in the way a crisis in an Accident and Emergency department may be, and tends to attract less media, political and popular attention. 
As well as analysing past and current spending, we have made long-term projections of adult social care spending based on the ratio of gross spending as a proportion of GVA. If the economy grows by $0.5 \%$ annually, projections of gross spending on adult social care to GVA, under the 'slow uptake' model, will exceed the highest levels of spending over the past two decades by 2028 ; this will happen by 2026 if the economy stays at 2018 levels, and by 2031 with economic growth at $1 \%$. These findings have two important implications. First, economic growth is crucial for sustaining adult social care, and future governments may be able to close the current funding gap if they pursue significant reforms and the economy grows significantly. Secondly, it is critical to implement adult social care reforms as soon as possible: governments will face greater financial stress the longer they wait to intervene in a system already at breaking point and in desperate need of reform. With yet more urgency than in 2010, we warn: 'Doing nothing is NOT an option'.

\section{Acknowledgements}

The authors gratefully acknowledge the support of the Economic \& Social Research Council (award ES/Poog255/1, Sustainable Care: connecting people and systems, 2017-21, Principal Investigator Sue Yeandle, University of Sheffield)

\section{Notes}

1 Government policy over time has separated out the design/purchasing of services ('commissioning') from their provision - and this scenario assumes that this policy focus remains, is taken seriously and starts to deliver some of the stated/assumed benefits

\section{References}

Age UK (2018), 'New analysis shows number of older people with unmet care needs soars to record high', London: Age UK, https://www.ageuk.org.uk/latest-press/articles/2018/july2018/new-analysis-shows-number-of-older-people-with-unmet-care-needs-soars-torecord-high/ [accessed 04.05.2019].

Age UK (2019), Care in crisis. London: Age UK, https://www.ageuk.org.uk/our-impact/ campaigning/care-in-crisis/ [accessed 04.05.2019].

Association of Directors of Adult Social Services (2019), ADASS budget survey 2019, ADASS, https://www.adass.org.uk/media/7295/adass-budget-survey-report-2019_final.pdf [accessed 04.05.2019].

Australian Government Productivity Commission (2010), Caring for older Australians: Productivity Commission issues paper. Canberra: Productivity Commission, https:// www.pc.gov.au/inquiries/completed/aged-care/report/aged-care-volume1.pdf [accessed 04.05.2019].

BBC (2019a), 'Four Seasons Health Care goes into administration', https://www.bbc.co.uk/ news/business-48102859 [accessed 22.05.2019].

BBC (2019b), 'Whorlton Hall: hospital 'abused' vulnerable adults', https://www.bbc.co.uk/ news/health-48367071 [accessed 22.05.2019]. 
British Household Panel Survey (2009), [computer file] Data files and associated documentation (ESRC Research Centre on Micro-social Change). Colchester: The Data Archive [distributor].

Butler, P. (2018), 'Adult social care services on brink of collapse, survey shows', The Guardian, 12 June.

Care Quality Commission (2018), 'Update on Allied Healthcare', https://www.cqc.org.uk/ news/stories/update-allied-healthcare [accessed 05.11.2018].

Carers Trust (2016), Care Act for carers: one year on. London: Carers Trust/University of Birmingham, https://carers.org/press-release/care-act-one-year [accessed 05.11.2018].

Carers UK (2019), State of caring survey 2019, London: Carers UK, https://www.carersuk.org/ news-and-campaigns/state-of-caring-survey-2019 [accessed 05.05.2019].

Competition and Markets Authority (2017), Care homes market study: final report, London: CMA, https://www.gov.uk/government/publications/care-homes-market-studysummary-of-final-report [accessed 05.05.2019].

Colombo, F., Llena Nozal, A., Mercier, J. and Tjadens, F. (2011), Help wanted?: providing and paying for long-term care, Paris: OECD Publishing (http://dx.doi.org/10.1787/ 9789264097759-en).

Conservative Party (2017), Forward together: the Conservative manifesto. London: Conservative Party, https://www.conservatives.com/manifesto [accessed 05.05.2019].

Cottam, H. (2018), Social work? Policing in the 21st century, http://www.hilarycottam.com/ social-work-policing-in-the-21st-century/ [accessed 05.05.2019].

Cromarty, H. (2019), Adult social care funding (England). London: House of Commons Library.

Department of Health (2010), A vision for social care: capable communities and active citizens', London: DH, http://www.cpa.org.uk/cpa_documents/vision_for_social_care2010.pdf [accessed 05.05.2019].

Department for Work and Pensions (2009), National Centre for Social Research and Office for National Statistics: Social and Vital Statistics Division, Family Resources Survey, 20072008 [computer file]. Colchester: UK Data Archive [distributor] (SN: 6252).

Dickinson, H., Shaw, S., Glasby, J. and Smith, J. (eds) (2013), 'The limits of market-based reforms', BMC Health Services Research, 13(1)

Dickson, N. (2019), Why we need a fair long-term funding settlement for social care, London: NHS Confederation, www.nhsconfed.org/blog/2019/03/health-for-care-op-ed).

Dilnot, A. (2011), Fairer care funding. London: Commission on Funding of Care and Support, www.ilis.co.uk/uploaded_files/dilnott_report_the_future_of_funding_social_care_july_ 2011.pdf [accessed 05.05.19].

Duffy, S. (2013), A fair society? How the cuts target disabled people, Sheffield: Centre for Welfare Reform/Campaign for a Fair Society, www.centreforwelfarereform.org/ uploads/attachment/354/a-fair-society.pdf [accessed 05.05.2019].

Duffy, S. (2014), 'After personalisation', in C. Needham and J. Glasby (eds) (2014), Debates in personalisation, Bristol: Policy Press.

Emerson, E. and C. Hatton (2008), Estimating future need for adult social care services for people with learning disabilities in England, Lancaster University: Centre for Disability Research (CeDR), https://eprints.lancs.ac.uk/id/eprint/21049/1/CeDR_2008-6_Estimating_Future_ Needs_for_Adult_Social_Care_Services_for_People_with_Learning_Disabilities_in_ England.pdf [accessed 05.05.2019].

Farnsworth, A. (2012), 'Unintended consequences? The impact of NHS reforms upon Torbay Care Trust', Journal of Integrated Care, 20(3): 146-151.

Glasby, J. (2015), 'The end of local government as we know it' - what next for adult social care?', in Z. Irving, M. Fenger, and J. Hudson (eds), Social Policy Review 27, Bristol: Policy Press. 
sby, J., Ham, C., Littlechild, R. and McKay, S. (2010), The case for social care reform - the wider economic and social benefits (for the Department of Health/Downing Street), Birmingham: Health Services Management Centre/Institute of Applied Social Studies.

Glendinning, C (2010), Dartington Review on the Future of Adult Social Care: what can England learn from the experiences of other countries?, Totnes: Research in Practice for Adults, http://eprints.whiterose.ac.uk/75160/1/Document.pdf [accessed 05.05.2019].

Henderson, C., Knapp, M., Fernandez, J-L., Beecham, J., Hirani, S. P., Beynon, M., Cartwright, M., Rixon, L., Doll, H., Bower, P., Steventon, A., Rogers, A., Fitzpatrick, R., Barlow, J., Bardsley, M. and Newman, S. P. (2014), 'Cost-effectiveness of telecare for people with social care needs: the Whole Systems Demonstrator cluster randomised trial', Age and Ageing, 43 (6): 794-800.

Henwood, M., McKay, S., Needham, C. and Glasby, J. (2018), From bystanders to core participants? A literature and data review of self-funders in social care markets. Birmingham: HSMC (on behalf of the Department of Health Policy Research Programme), https:// www.birmingham.ac.uk/Documents/college-social-sciences/social-policy/HSMC/ publications/2018/UoB-PRP-Self-funders-review-of-data-and-literature-FINAL.pdf [accessed 05.05.2019].

HM Government (2010), Building the National Care Service, London: TSO, https://assets. publishing.service.gov.uk/government/uploads/system/uploads/attachment_data/file/ 238441/7854.pdf [accessed 05.05.2019].

HM Government (2012), Draft Care and Support Bill. London: TSO, https://www.gov.uk/ government/publications/draft-care-and-support-bill-published [accessed 05.05.2019].

HM Government (2014), Care Act 2014. London: TSO, http://www.legislation.gov.uk/ukpga/ 2014/23/contents/enacted [accessed 05.05.2019].

HM Treasury (2018), GDP deflators at market prices, and money GDP, September 2018, https://www.gov.uk/government/statistics/gdp-deflators-at-market-prices-andmoney-gdp-september-2018-quarterly-national-accounts [accessed 12.09.2018].

Holt, A. (2019), 'The crisis in care: who pays?', BBC, www.bbc.co.uk/news/extra/ MYx8zCtDRI/the_crisis_in_care [accessed 15.04.2019].

House of Commons Communities and Local Government Committee (2017), Adult social care. London: TSO, www.parliament.uk/business/committees/committees-a-z/commonsselect/communities-and-local-government-committee/inquiries/parliament-2015/ adult-social-care-16-17/ [accessed 18.04.2019].

House of Commons Health and Social Care and Housing, Communities and Local Government Committees (2018), Long-term funding of adult social care, London: House of Commons, https://publications.parliament.uk/pa/cm201719/cmselect/cmcomloc/768/768.pdf [accessed 18.04.2019].

House of Lords Economic Affairs Committee (2019), Social care funding: time to end a national scandal. London: House of Lords, https://publications.parliament.uk/pa/ ld201719/ldselect/ldeconaf/392/392.pdf [accessed 18.04.2019].

Hudson, B. (2016), The unsuccessful privatisation of social care: why it matters and how to curb it, http://blogs.lse.ac.uk/politicsandpolicy/why-social-care-privatisation-is-unsuccessful/ [accessed 18.04.2019].

Humphries, R., Thorlby, R., Holder, H., Hall, P. and Charles, A. (2016), Social care for older people: home truths. London: King's Fund/Nuffield Trust, www.kingsfund.org.uk/sites/default/files/ field/field_publication_file/Social_care_older_people_Kings_Fund_Sep_2016.pdf [accessed 18.04.2019].

Jarrett, T. (2018), Social care: announcements delaying the introduction of funding reforms (including the cap) (England), London: House of Commons Library.

Jarrett, T. (2019), Adult social care: the Government's ongoing policy review and anticipated Green Paper (England). London: House of Commons Library. 
Johnson, P. (2019), Our pension and social care systems load too much risk onto individuals. London: Institute for Fiscal Studies, https://www.ifs.org.uk/publications/14144 [accessed 18.04.2019].

Kontopantelis, E. (2018), 'Give millennials a break - young people are worse off and it's not their fault', The Conversation: 27 March, http://theconversation.com/give-millennials-abreak-young-people-are-worse-off-and-its-not-their-fault-93833 [accessed 18.04.2018].

Law Commission (2011), Adult social care. London: TSO.

Local Government Association (2019), Council tax will fail to protect adult social care services this year. LGA, 6 March https://www.local.gov.uk/about/news/council-tax-will-failprotect-adult-social-care-services-year [accessed 18.03.2019].

Mencap (2016), Stuck at home: the impact of day service cuts on people with a learning disability. London: Mencap, www.mencap.org.uk/sites/default/files/2016-08/Stuck_at_home. pdf [accessed 18.12.2016].

National Audit Office (2018), The adult social care workforce in England, London: NAO, www. nao.org.uk/wp-content/uploads/2018/02/The-adult-social-care-workforce-in-England. pdf [accessed 18.12.2018].

NHS Digital (2019a), Personal social services survey of adult carers in England. Leeds: NHS Digital.

NHS Digital (2019b), Personal social services: staff of Social Services Departments, England as at September 2018. Leeds: NHS Digital.

Nuffield Trust (2019), Delayed transfers of care, www.nuffieldtrust.org.uk/resource/delayedtransfers-of-care [accessed 04.02.2019].

Office for National Statistics, General Register Office for Scotland and Northern Ireland Statistics and Research Agency (computer file) (2001), 2001 Census: Sample of Anonymised Records (SARs) (Licensed) (England, Wales, Scotland and Northern Ireland). ESRC/JISC Census Programme, Cathie Marsh Centre for Census and Survey Research, University of Manchester.

Office for National Statistics, Social and Vital Statistics Division and Northern Ireland Statistics and Research Agency: Central Survey Unit (computer file) (2009), Quarterly Labour Force Survey, January-March, 2009. Colchester: UK Data Archive [distributor] (SN: 6199).

Shaw, K.A. (2018), Baby Boomers versus Millennials: rhetorical conflicts and interest-construction in the new politics of intergenerational fairness. Sheffield: Sheffield Political Economy Research Institute/Foundation for European Progressive Studies, http://speri.dept.shef. ac.uk/wp-content/uploads/2018/11/Baby-Boomers-versus-Milennials-Kate-AlexanderShaw.pdf [accessed 16.10.2018].

Tarricone, R. and Tsouros, A. D. (eds) (2008), The solid facts: home care in Europe. Copenhagen: World Health Organization Regional Office for Europe. http://www.euro.who.int/_data/ assets/pdf_file/0005/96467/E91884.pdf?ua=1 [accessed 16.10.2018].

Trades Union Congress (2018), Breaking point: the crisis in mental health funding. London: TUC, www.tuc.org.uk/sites/default/files/Mentalhealthfundingreport2_o.pdf [accessed 23.04.2019].

Wanless, D. (2002), Securing our future health: taking a long-term view - final report. London: HM Treasury, https://www.yearofcare.co.uk/sites/default/files/images/Wanless.pdf [accessed 23.04.2018].

Wittenberg, R., Hu, B. and Hancock, R. (2018), Projections of demand and expenditure on adult social care 2015 to 2040. London: LSE/PSSRU, http://eprints.lse.ac.uk/88376/1/ Wittenberg_Adult\%20Social\%20Care_Published.pdf [accessed 26.04.2019].

Wittenberg, R., Pickard, L., Comas-Herrera, A., Davies, B. and Darton, R. (1998), Demand for long-term care: projections of long-term care finance for elderly people, Canterbury: Personal Social Services Research Unit/London School of Economics, https://www. pssru.ac.uk/pub/ltcrep98.pdf [accessed 23.04.2019]. 
Wittenberg, R., Pickard, L., Malley, J., King D., Comas-Herrera, A. and Darton, R. (2008a), Future demand for social care, 2005 to 2041: projections of demand for social care for older people in England. Canterbury: Personal Social Services Research Unit, https://www. pssru.ac.uk/pub/dp2514.pdf [accessed 23.04.2019].

Wittenberg, R., Malley, J., Comas-Herrera, A., Fernandez, J-L., King D., Snell, T. and Pickard, L. (2008b), Future demand for social care, 2005 to 2041: projections of demand for social care and disability benefits for younger people in England. Canterbury: Personal Social Services Research Unit, https://www.pssru.ac.uk/pub/dp2512.pdf [accessed 23.04.2019].

Yates, E. (2019), 'How Britain's economy has wronged young people for decades', The Conversation: 28 February, http://theconversation.com/how-britains-economy-haswronged-young-people-for-decades-111444 [accessed 23.03.2019]. 


\title{
Appendix: cost projections
}

\author{
2010 analysis
}

Sources of data: the cost projections discussed throughout the report are based on a number of simplifying assumptions, applied to data of various kinds. The data underlying the projections are drawn from:

- ONS population projections - for numbers of people of different ages, and of different living arrangements (couple versus single). Such data is crown copyright (ONS, 2001)

- Census 2001 - for proportions of older people living in residential settings

- BHPS 2007-08 (wave 17) for receiving services among those living at their own residences (BHPS, 2009)

- PSS expenditure data of different kinds, from the DH Information Centre

- Estimates of the number of disabled people with learning disabilities (from Emerson and Hatton, 2008)

- Estimates of the work patterns of informal carers, from the Family Resources Surveys of 2003/04 and 2007/08 (the latest available) - DWP, 2009

- Analysis of the work participation rates of disabled and non-disabled people, from the quarterly Labour Force Surveys of Jul-Sep 2004 and Jul-Sep 2009 (ONS, 2009)

- Analysis of sickness absence rates from the same source

Methods: separate ad hoc approaches were used to estimate the potential cost savings from having more disabled people and carers back in the labour force. The main assumptions were of pay rates at the minimum wage (pessimistic) and full-time employment (optimistic).

The methodology used to analyse overall spending projections was that of cellbased simulation. This is a robust approach that has often been deployed to project future spending (see, for example, Wittenberg et al., 2008a, 2008b). It is based on attributing outcomes to pre-specified groups in the population - such as the chances of being in residential care for groups defined by age, gender and marital status. The numbers of people in each group change each year, drawing on data from population projections. The product of the size of the group, and the associated incidence of care needs, multiplied by a cost factor, generates the components of the cost projections.

An alternative approach - micro-simulation - may be used to look at results at the level of individuals, but imposes greater requirements in terms of data and of programming the models (Wittenberg et al., 1998). Developing new micro-simulation models was not possible given the short duration of this review. However it was possible to construct simple cell-based simulations to suggest how 
spending might develop in future if a host of assumptions about the incidence of care and its costs continue to be met. These were projections, not predictions.

Selecting the scenarios: in our 2010 report we outlined a number of strategies that might generate cost savings, and improved outcomes. These have been quite substantial in some instances, but more limited in other areas. There were also strong and important differences in the robustness of the evidence, and the confidence that may be placed in different estimates of areas of saving.

Even given these factors, it is not possible to simply 'add up' the kinds of savings proposed to reach an overall figure. Some of the savings were in different areas of spending and so it would be double-counting to include both sets (for example, greater personalisation of care budgets, and the role of commissioning). There was also limited data on whether the cost savings achievable may be regarded as a 'one-off reduction or instead may be treated as dynamic factors that continue to reduce future costs by similar proportions. In many cases the future savings may require upfront investment, in new procedures or infrastructure, that need to be included in the round.

For these reasons the overall scenarios modelled (a $2 \%$ reduction in costs under a 'fully engaged' scenario, no change in costs under a 'solid progress' scenario, and a $2 \%$ increase in a 'slow uptake' scenario) were based on the kinds of figures found within each strategy and were not attempts to naively sum up the sets of individual financial assumptions.

What the projections demonstrated was the large momentum built into the future costs of social care by population change. The overall costs in real terms continued to increase quite sharply even if there was no change in the real unit costs of care provision. Even if costs could be cut by two per cent annually in real terms - a demanding challenge - the effect was barely to constrain real levels of spending to their current level.

A critical assumption made was that there are no 'start-up' costs to the reforms. In reality many of the proposed reforms might cost more in the short term, even if they saved money in the longer term. However there was very limited information available about the size of such costs, and they had not been a focus for research.

\section{9 analysis}

Sources of data: the projections on the adult social care cost in this article are based on a series of assumptions. The data applied in the projections are obtained from:

- ONS 2016-based population projections - for numbers of people across different ages 
- Adult Social Care Activity and Finance Report, England - 2017-18 - for the number of people who receive support by care type and age group and for spending on adult social care by long-term and short-term support and by age group

- The regional gross value added (GVA), Office for National Statistics 2018

Methods: We assume the proportion of people at different age groups receiving long-term and short-term support is constant. Following the 2010 analysis, care cost is assumed to increase by $2 \%$ under the 'slow uptake' scenario, remain constant under the 'solid progress' scenario, and reduce by $2 \%$ under the 'fully engaged' scenario.

'Slow uptake':

$$
\begin{aligned}
\text { Projectedcost }_{j i t}= & \frac{\text { ASCCosts }_{j i 2018}}{\text { Population }_{j 2018} * \text { RateCare }_{j i 2018}} * \text { Population }_{j t} \\
& * \text { RateCare }_{j i 2018} *(1+2 \%)^{t-2018}
\end{aligned}
$$

'Solid progress':

$$
\begin{aligned}
\text { Projectedcost }_{j i t}= & \frac{\text { ASCCosts }_{j i 2018}}{\text { Population }_{j 2018} * \text { RateCare }_{j i 2018}} * \text { Population }_{j t} \\
& * \text { RateCare }_{j i 2018}
\end{aligned}
$$

'Fully engaged':

$$
\begin{aligned}
\text { Projectedcost }_{j i t}= & \frac{\text { ASCCosts }_{j i 2018}}{\text { Population }_{j 2018} * \text { RateCare }_{j i 2018}} * \text { Population }_{j t} \\
& * \text { RateCare }_{j i 2018} *(1-2 \%)^{t-2018}
\end{aligned}
$$

Projectedcost $_{j i t}$ represents the projected costs of adult social care support for age group $\mathrm{j}$ ( $\mathrm{j}=1$ or 2,1 for those aged 16-64 and 2 for those aged 65 and over) and support type $\mathrm{i}$ ( $\mathrm{i}=1$ or 2,1 for LT support and 2 for ST support) in year $\mathrm{t}$ $(t=2018,2019, \ldots, 2060)$. ASCCosts Ai2018 $_{j}$ is the actual gross spending on adult social care for age group $\mathrm{j}$ and support type $\mathrm{i}$ in 2018. Population $\mathrm{P}_{j t}$ is the number of population for age group $\mathrm{j}$ in year t. RateCare ii2018 $_{1}$ is the ratio of people in age group j who receive adult social care support under type i in 2018. We assume that the economy grows at $2 \%$ based on data for the past 20 years. The projected GVA in a specific year $t$ is:

$$
G V A_{t}=G V A_{2018} *(1+2 \%)^{t-2018}
$$


The proportion of gross spending on the adult social care is calculated as:

$$
\operatorname{Cost} 2 G V A_{j i t}=\frac{\text { Projected }_{\text {cost }} \text { jit }_{\text {f }}}{G V A_{t}}
$$

